\title{
Pengembangan Desain Pembelajaran Basic Mathematic dengan Metode Estafet Kartu
}

\author{
Kresna Oktafianto $^{1 *}$; Eriska Fitri Kurniawati² Lilik Muzdalifah $^{3}$; Ahmad Zaenal Arifin ${ }^{4}$; Nia \\ Nurfitria $^{5}$; Afifah ${ }^{6}$; Ridho Awanda ${ }^{7}$ \\ $1^{*}$ Prodi Matematika FMIPA Universitas PGRI Ronggolawe Tuban, Indonesia \\ 1*kresnaoktafianto@unirow.ac.id
}

\begin{abstract}
Abstrak
Pendidikan dasar sangat penting bagi generasi penerus bangsa. Zaman yang terus berkembang menuntut para pendidik untuk melakukan strategi pembelajaran yang kreatif dan inovatif. Pendidikan dasar yang terpusat pada siswa-siswa SD menjadi pusat perhatian, sering kali pelajaran matematika menjadi momok yang berat bagi siswa SD. Oleh karena itu, pembelajaran matematika pada siswa SD juga membutuhkan strategi pembelajaran yang berbeda dari sebelumnya. Tujuan dari program Rumah Matematika (RuMat) kepada masyarakat khususnya siswa SD adalah untuk mengubah mindset pelajaran matematika yang seringkali menjadi momok siswa menjadi pelajaran yang menyenangkan dengan menerapkan Metode Estafet Kartu. Metode tersebut lebih ke dalam bentuk permainan sehingga siswa dapat menyerap ilmu sambil bermain. Dengan adanya program Rumah Matematika (RuMat), siswa lebih berminat dalam mempelajari matematika dasar dengan cara yang lebih menyenangkan.
\end{abstract}

Kata Kunci: Pendidikan, Pelajaran Matematika, Rumah Matematika (RuMat), Estafet Kartu

\section{Abstract}

Basic education is very important for the next generation of the nation. A growing era requires educators to implement creative and innovative learning strategies. Basic education that is centered on elementary students is the center of attention, often mathematics lessons become a heavy scourge for elementary students. Therefore, learning mathematics in elementary students also requires learning strategies that are different from before. The purpose of the Rumah Matematika (RuMat) program for the community especially elementary students is to change the mindset of mathematics lessons that often scourge students into fun lessons by applying the Card Relay Method. The method is more in the form of a game so students can absorb knowledge while playing. With Rumah Matematika (RuMat) program, students will be more interested in learning basic mathematics in a more fun way.

Keywords: Education, Math, Home of Mathematic, Card Relay

\section{Pendahuluan}

Pendidikan dasar sangat penting bagi setiap anak untuk meningkatkan kualitas generasi bangsa. Di Indonesia telah ditetapkan Undang-Undang yang mewajibkan setiap anak untuk melaksanakan pendidikan sekunder salah satunya pada sekolah dasar (Pemerintah Indonesia, 2005). Strategi pendidikan di Indonesia selalu dievaluasi di beberapa periode menjadi lebih baik. Para pendidik berupaya untuk menciptakan strategi pendidikan yang lebih menarik minat siswa untuk belajar terutama siswa sekolah dasar (Fitriani dan Maulana, 2016)(Effendi, 2012). Hal tersebut tentu saja untuk menjadikan siswa memiliki pondasi yang kuat dalam pendidikan dasar sehingga lebih mudah dalam memahami pelajaran di tingkat yang lebih tinggi.

Saat ini sudah ada banyak strategi pendidikan yang diciptakan dan direalisasikan. Namun perealisasian masih belum dilaksanakan secara menyeluruh (Fitriani dan Maulana, 2016). Seperti contoh di Kabupaten Tuban, masih ada beberapa sekolah dasar yang belum memiliki strategi pendidikan yang lebih baik. Salah satu sekolah tersebut antara lain SDN Sidomulyo I Tuban. Para siswa di sekolah dasar tersebut belum mempunyai pondasi kuat di beberapa mata pelajaran. Pondasi yang paling lemah salah satunya ada pada pelajaran matematika (Gunantara dkk, 2014)(Amir, 2015).

Setiap sekolah pasti memiliki strategi pembelajaran bagi para siswanya, akan tetapi seringkali yang menjadi kendala adalah kemampuan masing-masing siswa yang berbeda-beda. Hal ini mengakibatkan penerapan strategi pembelajaran menjadi tidak efisien. Selain itu, permasalahan yang seringkali dihadapi siswa adalah mata pelajaran matematika. Seringkali mata pelajaran matematika menjadi tolok ukur kecerdasan siswa. Sedangkan pada kenyataannya seringkali nilai siswa jatuh di mata pelajaran matematika (Fitriani dan Maulana, 2016). Hal ini terjadi dikarenakan 2 kemungkinan yaitu : 1) 
Kemampuan siswa yang tidak mengarah pada konsep eksak tetapi dipaksakan 2) Strategi pembelajaran matematika yang masih kurang efisien.

Untuk mengatasi kedua masalah tersebut, solusi yang ditawarkan berupa "RuMat" Rumah Matematika sebagai Sarana Pengenalan Matematika Dasar bagi Siswa Sekolah Dasar. Konsep yang ada di RuMat sendiri lebih cenderung membantu guru dalam memberikan konsep strategi belajar Matematika yang berbeda dari yang diberikan guru pada umumnya. Konsep RuMat lebih ke dalam bentuk permainan sehingga siswa dapat menyerap ilmu sambil bermain.

\section{Bahan dan Metode}

Untuk menyelesaikan permasalahan tersebut, tim pelaksana akan memberikan program berupa "RuMat" Rumah Matematika sebagai Pengembangan Desain Pembelajaran Basic Mathematic dengan Metode Estafet Kartu bagi siswa Sekolah Dasar. Konsep yang ada di RuMat sendiri lebih cenderung membantu guru dalam memberikan konsep strategi belajar Matematika yang berbeda dari yang diberikan guru pada umumnya. Konsep RuMat lebih ke dalam bentuk permainan estafet kartu sehingga siswa dapat menyerap ilmu sambil bermain.

\section{Hasil dan Pembahasan}

Kegiatan ini dilaksanakan pada dua kelas yaitu kelas II dan III di SDN Sidomulyo I Tuban selama empat kali pertemuan pada bulan September 2019 dengan jumlah siswa kelas II sebanyak 25 siswa dan kelas III sebanyak 30 siswa. Pada pertemuan pertama, siswa diberikan pre test untuk mengukur tingkat pemahaman tiap siswa terhadap matematika dasar. Hasil pre test siswa ditunjukkan dalam diagram berikut:
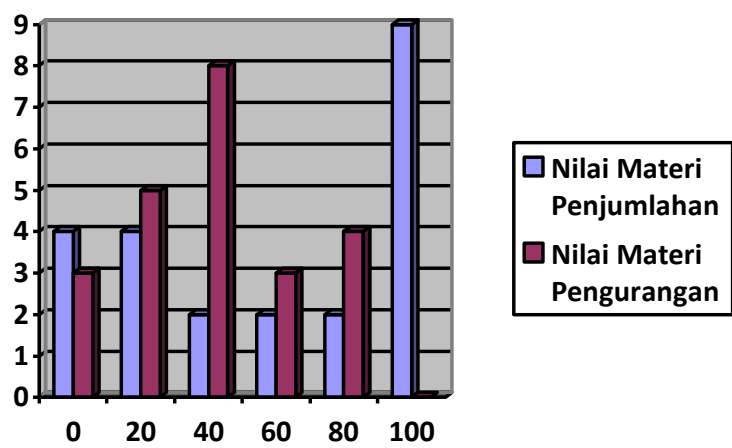

Gambar 1 Hasil Pre Test Siswa Kelas 2

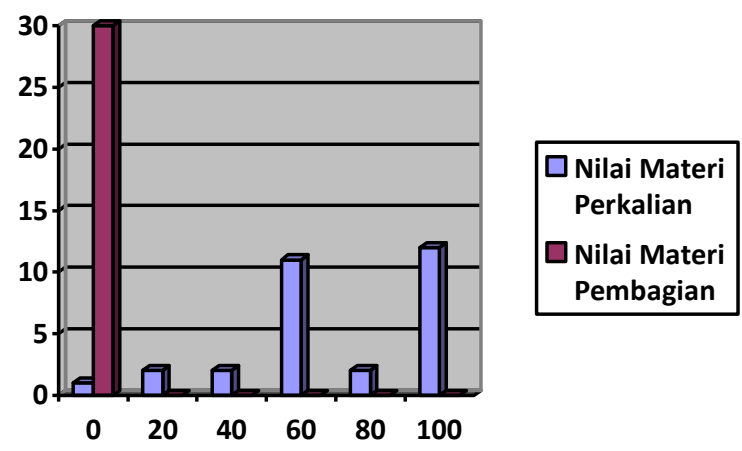

Gambar 2 Hasil Pre Test Siswa Kelas 3

Hasil pre test yang telah dikerjakan menjadi tolak ukur tingkat pemahaman siswa dan digunakan sebagai salah satu tindaklanjut untuk memulai pembelajaran selanjutnya. Pada pertemuan kedua dan ketiga dilaksanakan kegiatan pembelajaran dengan materi pembelajaran sebagai berikut:

Tabel 1.

Materi Pembelajaran

\begin{tabular}{ccc}
\hline Kelas & Pertemuan ke & Materi \\
\hline \multirow{2}{*}{ II } & 2 & Penjumlahan \\
& 3 & Pengurangan \\
\hline \multirow{2}{*}{ III } & 2 & Perkalian \\
& 3 & Pembagian \\
\hline
\end{tabular}

Pada pertemuan keempat, dilaksanakan sistem pembelajaran dengan menggunakan metode estafet kartu. Pembelajaran ini dimulai dengan pembentukan kelompok yang terdiri dari 5-6 siswa. Setiap siswa per kelompok akan maju ke depan secara bergiliran untuk mengerjakan soal yang diberikan oleh tim pelaksana. Disediakan tiga set kartu angka dengan angka 0 sampai 9. Tim pelaksana akan memberikan soal yang akan dijawab oleh siswa dengan menyusun kartu angka sesuai jawaban yang tepat. Kelompok yang paling banyak menjawab soal dengan benar memenangkan permainan.

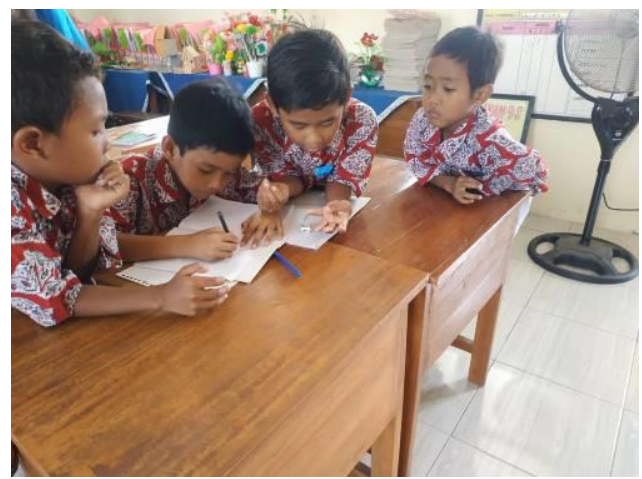

Gambar 3 Diskusi Kelompok 
Setelah kegiatan tersebut, siswa diberi post test untuk mengetahui peningkatan pemahaman setiap siswa dalam matematika dasar.

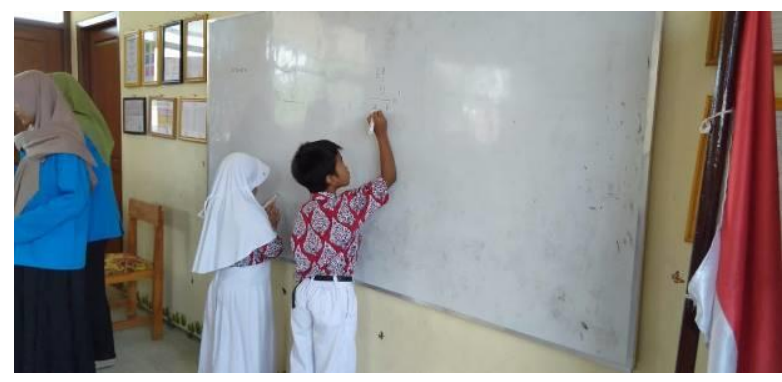

Gambar 4 Tim Pelaksana Memberi Tantangan Soal Kepada Siswa

\section{Kesimpulan dan Saran}

Dengan adanya program ini, siswa mempelajari matematika dasar dengan cara yang lebih menyenangkan sehingga minat siswa meningkat. Siswa lebih berminat mempelajari matematika dasar dengan metode estafet kartu daripada dengan cara pembelajaran biasa oleh guru yang kurang menarik bagi siswa. Selain itu, kegiatan ini meningkatkan kemampuan siswa dalam bekerja secara individual maupun bekerja secara kelompok.

Semoga dengan adanya program ini, siswa dapat lebih berminat untuk mempelajari matematika dasar. Para guru juga dapat menerapkannya pada sistem pembelajaran sehingga para siswa lebih bersemangat dalam mempelajari matematika dasar.

\section{Ucapan Terima Kasih}

Kegiatan pengabdian masyarakat melalui konsep RuMat (Rumah Matematika) di kelas 2 dan 3 SD Sidomulyo 1 bisa berlangsung karena beberapa pihak yang telah mendukung atau berjasa. Untuk itu, tim pelaksana haturkan banyak terima kasih kepada Universitas Ronggolawe Tuban, khususnya Lembaga Pengabdian kepada Masyarakat, mahasiswa prodi matematika, serta para siswa/i SD Sidomulyo 1 yang sangat semangat dan antusias.

\section{Daftar Rujukan}

Amir, M. F. (2015). Pengaruh Pembelajaran Kontekstual Terhadap Kemampuan Pemecahan Masalah Matematika Siswa Sekolah Dasar. Prosiding Seminar Nasional Pendidikan, pp. 34-42.

Effendi, L. A. (2012). Pembelajaran Matematika dengan Metode Penemuan Terbimbing untuk Meningkatkan Kemampuan Representasi dan Pemecahan Masalah Matematis Siswa SMP. Jurnal Penelitian Pendidikan, 13(2), pp. 1-10.
Fitriani, K. \& Maulana, M. (2016). Meningkatkan Kemampuan Pemahaman dan Pemecahan Masalah Matematis Siswa SD Kelas V Melalui Pendekatan Matematika Realistik. Mimbar Sekolah Dasar, 3(1), pp. 40-52.

Gunantara, G., Suarjana, I. M. \& Riastini, P. N. (2014). Penerapan Model Pembelajaran Problem Based Learning untuk Meningkatkan Kemampuan Pemecahan Masalah Matematika Siswa Kelas V. MIMBAR PGSD Undiksha, 2(1).

Pemerintah Indonesia. (2005). Undang-Undang Nomor 19 Tahun 2005 tentang Standar Nasional Pendidikan. Lembaran Negara RI Tahun 2005 No. 19. Sekretariat Negara. Jakarta. 